não são as principais da obra, estes têm dificuldade muito grande por falta de tradição no mercado e pela dificuldade que os bancos têm hoje de atender a exportadores por falta de instrumental jurídico ou de câmbio, na necessidade eventual de remessas urgentes de divisas. Quando muito poderiam socorrerse de divisas fornecidas pelas unidades externas dos bancos, mas sem uma garantia para o banco de que essas divisas pudessem depois transitar rapidamen- te do Brasil para o exterior, para cobrir as eventuais despesas ou até eventuais prejuízos desses pequenos exportadores.

Essa é a matéria que merece hoje atenção maior, para que nós possamos ampliar a exportação, não em volumes enormes com poucas operações, mas em volume apreciável de operações de menor valor.

\title{
Diferenças entre o sistema brasileiro e europeu de seguro de crédito à exportação
}

Hans Joachim Pretzell, diretor da Empresa Kluckner Group Company, Londres.
Os europeus estão realmente melhor protegidos. O Clube de Berna (Bern Union ), por exemplo, que congrega quese todos os países industrializados, regulamentou as diferentes modalidades de crédito. Alguns sistemas são sofisticados, como o francês e o inglês. No sistema inglês, um dos grandes riscos, por exemplo nas licitações internacionais, é a manutenção de um preço estável: o governo inglês provê, através do Departamento de Garantia de Crédito à Exportação - ECGD, a possibilidade de um seguro de inflação durante o período de licitação e o de construção da fábrica, contemplando projetos que, às vezes, se prolongam por doze meses.

Outra facilidade inglesa, não-existente no Brasil, é a escolha de uma moeda mais barata do que a libra esterlina (sempre muito forte, em virtude das taxas de juro), facultada ao exportador de bens de capital em meio a competidores, digamos, do Japão, que oferecem o produto em Yen. Outra facilidade, ainda existente sobretudo na França e na Inglaterra, são os chamados buyer's credits, os quais habilitam o exportador a calcular o preço contratual à base de um preço à vista cash-price, o que implica em assumir o governo inteiramente os riscos políticos e comerciais pelo não-reembolso do comprador estrangeiro, vantagem esta extraordinária sobre países como o Japão ou a Alemanha Ocidental, que adotam o supplier's credit, pelo qual o exportador se obriga a calcular uma participação entre 15 e $25 \%$ conforme a credibilidade do comprador. Nas facilidades vigentes no Reino Unido: oferecimento de um conjunto de apólices (big bond), que podem também ser seguradas, minimizando o risco do exportador; seguro contra insolvência ou dificuldades financeiras de um sócio estrangeiro durante a execução de um contrato.

Tais são as grandes vantagens existentes na Europa Ocidental, às quais ainda se poderiam acrescentar os esquemas internacionais de financiamento à exportação, que se tornam cada vez mais sofisticados, a fim de se superarem uns aos outros na conquista dos escassos projetos, razão por que, a despeito de todos os acordos e protocolos, cada país concentra esforços no sentido de uma ou duas regras em casos específicos.

A questão final prende-se ao estabelecimento da garantia de credibilidade de um país receptor, o que é um procedimento secreto entre as nações da Bern Union, as quais se reúnem uma vez por mês para troca de experiências. No Reino Unido, por exemplo, existem quatro diferentes categorias de garantias, sendo o prêmio a ser pago pelo exportador à ECDG, na dependência da credibilidade do país, como já visto, conservado em segredo, de modo que no país do cliente não se possa saber a posição do crédito junto às autoridades inglesas, francesas ou alemãs. 